$10-18-2013$

\title{
Catalytic Methyl Transfer from Dimethylcarbonate to Carboxylic Acids
}

Yuan Ji

Jessica Sweeney

Jillian Zoglio

David J. Gorin

Smith College,dgorin@smith.edu

Follow this and additional works at: https://scholarworks.smith.edu/chm_facpubs

Part of the Chemistry Commons

\section{Recommended Citation}

Ji, Yuan; Sweeney, Jessica; Zoglio, Jillian; and Gorin, David J., "Catalytic Methyl Transfer from Dimethylcarbonate to Carboxylic Acids" (2013). Chemistry: Faculty Publications, Smith College, Northampton, MA.

https://scholarworks.smith.edu/chm_facpubs/6 


\section{Catalytic Methyl Transfer from Dimethylcarbonate to Carboxylic Acids}

Yuan Ji, Jessica Sweeney, Jillian Zoglio, and David J. Gorin*

Department of Chemistry, Smith College, Northampton, MA 01063

dgorin@smith.edu

Abstract:

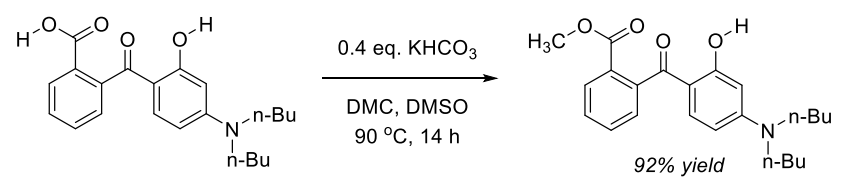

Although methylation reactions are commonplace, currently used reagents are hazardous, toxic, and/or unstable. Dimethylcarbonate has been put forth as an inexpensive, non-toxic, and "green" potential methylating reagent. Herein we report a general, base-catalyzed methyl transfer from dimethylcarbonate to carboxylic acids. High selectivity for esterification is observed even in the presence of unprotected phenols and the mild reaction conditions enable conservation of stereochemistry at epimerizable stereocenters. Isotope-labeling studies suggest a mechanism proceeding by direct methyl transfer from dimethylcarbonate to the substrate. 
Methylation reactions of carboxylic acids are ubiquitously used in chemical research, including in natural product synthesis, ${ }^{1}$ reaction development, ${ }^{2}$ medicinal chemistry, ${ }^{3}$ and polymer synthesis. ${ }^{4}$ Although often effective, Fisher esterification is incompatible with acid-sensitive substrates. ${ }^{5}$ This led to the development of electrophilic methylating reagents that react under mild conditions, such as diazomethane, dimethyl sulfate, and "magic methyl."6

Perhaps the most high-profile drawback of common methylating reagents is their extraordinary acute toxicity. ${ }^{7-10}$ For example, trimethylsilyl diazomethane, sometimes considered a safer alternative to diazomethane due to its decreased volatility and increased stability, ${ }^{11}$ has caused the deaths of two chemists since $2008 .{ }^{7}$ Use of common methylating agents, including diazomethane, trimethylsilyldiazomethane, dimethyl sulfate, and iodomethane, is also complicated by their general instability to light, heat, and/or moisture, along with concerns about chronic health risks. ${ }^{7-11}$ Despite their drawbacks, hazardous methylating reagents are regularly used in both academic and industrial laboratories..$^{1-4}$

We have therefore initiated a program to develop new methylation methods that rely upon safe, stable reagents. While others have sought to mitigate the hazards of current reagents, ${ }^{12-13}$ the development of non-explosive carbene precursors ${ }^{14}$ and safer alternatives to hydrogen cyanide ${ }^{15}$ inspired us to pursue altogether different methylating agents. ${ }^{16}$ Increased safety and convenience will reduce the cost and risk of an immensely useful functional group manipulation.

Dimethylcarbonate (DMC, $\mathbf{1}$ ) is an inexpensive, non-toxic, and "green" potential methylating reagent. ${ }^{17-19}$ Although DMC has been explored in methylations of a variety of nucleophiles, esterifications have generally been limited to electron-rich carboxylic acids and require stoichiometric activating agents, high $\left(>150^{\circ} \mathrm{C}\right)$ temperature, and/or special reactors such as autoclaves. ${ }^{20-28}$ Perhaps due to the limited demonstrated substrate scope and harsh reaction conditions, methylation with DMC has not found routine application in synthetic organic chemistry.

Herein we report a general catalytic methyl transfer from DMC to carboxylic acid nucleophiles under basic conditions. ${ }^{29}$ Both electron-rich and electron-poor substrates are readily esterified and the mild reaction 
conditions enable conservation of stereochemistry at epimerizable $\alpha$-carbonyl stereocenters. Mechanistic studies suggest that a direct methyl transfer from DMC, rather than a carbonyl substitution mechanism, is operative. The improved substrate scope and chemoselectivity demonstrated in this work suggest that DMC should be considered as an alternative to routinely-used hazardous methylating agents.

Our starting point for reaction development was Shieh's seminal report on methylation of carboxylic acids using stoichiometric DBU to activate DMC. ${ }^{20,30-31}$ We hypothesized that co-solvents or less basic catalysts might ameliorate the need for stoichiometric quantities of catalyst. ${ }^{32}$ Conversion of benzoic acid (2a) to methyl benzoate (3a) was quantified by GCMS. Under solvent-free conditions, catalytic quantities of DBU mediated the formation of $3 a$ in only $5 \%$ yield (Table 1, entry 1 ). Dramatic solvent effects were observed (entries 2-4). While increased 3a was formed in DMF, higher yield and apparent catalyst turnover resulted from the reaction in DMSO. ${ }^{33}$

\section{Table 1. Optimization of Base-Catalyzed Esterification.}

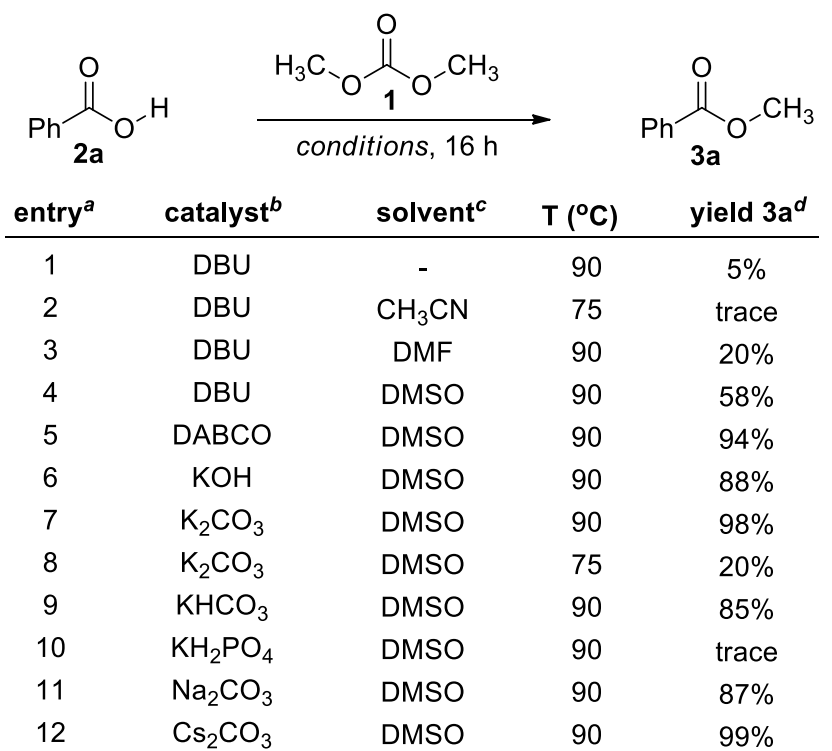

a) Ratio of $1: 2 \mathrm{a}=20: 1 . b) 0.2$ equiv. $c)[2 \mathrm{a}]=0.2 \mathrm{M}$.
d) Determined by GCMS against an internal standard

Other catalysts were investigated in DMSO. DABCO catalyzed formation of $\mathbf{3 a}$ in high yield (Table $\mathbf{1}$, entry 5). ${ }^{32}$ Surprisingly, inorganic bases such as $\mathrm{K}_{2} \mathrm{CO}_{3}$ and $\mathrm{KOH}$ catalyzed formation of $3 \mathbf{a}$ with similar efficiencies at $90{ }^{\circ} \mathrm{C}$ (entries 6-7). ${ }^{34}$ Although the $\mathrm{K}_{2} \mathrm{CO}_{3}$-catalyzed reaction still proceeded at lower 
temperature, the rate was greatly slowed; only $20 \%$ conversion to $3 a$ was observed at $75{ }^{\circ} \mathrm{C}$ (entry 8 ). Although $\mathrm{KHCO}_{3}$ effectively catalyzed formation of $3 \mathbf{a}, \mathrm{KH}_{2} \mathrm{PO}_{4}$ did not (entries 9-10). This suggests that sufficient basicity to deprotonate the nucleophile is necessary. The methylation proceeded regardless of the countercation used (entries 11-12).

Potassium carbonate was chosen for further investigation owing to its mild basicity, low cost, and high yield of product formed. The conditions discovered through GCMS screening were readily adaptable to synthetically useful scale. Methyl benzoate was synthesized on a $1 \mathrm{~g}$ scale in $93 \%$ isolated yield (Table 2 , entry 1 ), although increased catalyst loading ( 0.4 equiv.) was necessary to maintain reasonable reaction time. Unlike in methylation with diazo reagents, no acidic quench was required; 3 pure $3 \mathbf{a}$ was obtained after simple aqueous workup without need for further purification (see Experimental Section).

The substrate scope and functional group compatibility of the $\mathrm{K}_{2} \mathrm{CO}_{3}$-catalyzed methylation were investigated. Electron-rich benzoic acid derivatives were readily esterified (Table 2, entries 2-4). The reaction of 2-anisic acid (2c) proceeded in excellent yield even with decreased catalyst loading (entry 3).

In contrast to previous esterification reactions that employ DMC, electron-withdrawing groups were also well-tolerated (Table 2, entries 5-9).20-27 Given the reported difficulties with electron-poor substrates, the successful esterification of 2-nitrobenzoic acid $(\mathbf{2 h}, \mathrm{pKa}=2.2)$, which is far more acidic than even 4nitrobenzoic acid $(\mathbf{2 g}, \mathrm{pKa}=3.4), 35$ is particularly noteworthy (entry 8$)$.

The methylation readily proceeded even with sterically hindered substrates. Ortho-disubstituted ester $\mathbf{3 k}$ was synthesized in high yield (Table 2, entry 11). Furthermore, neopentylic ester $3 \mathrm{~m}$ was formed as efficiently as unhindered ester $\mathbf{3 I}$ (entries $12-13$ ).

An array of functional groups were compatible with the reaction conditions, including thioethers, aldehydes, and aryl halides (Table 2, entries 4, 6,10). The successful methylation of acid-sensitive substrate with acetal and Boc-carbamate moieties illustrates the complementarity of this method to acidmediated Fisher esterification (entries 2, 14). 
Table 2. Scope of the Methylation

\begin{tabular}{|c|c|c|}
\hline O & 0.4 eq $\mathrm{K}_{2} \mathrm{CO}_{3}$ & $\mathrm{O}$ \\
\hline $2 a-p$ & $\begin{array}{c}\text { DMC, DMSO } \\
90^{\circ} \mathrm{C}, 16 \mathrm{~h}\end{array}$ & 3a-p \\
\hline Entry & Product & Isolated Yield \\
\hline 1 & $X=H \quad 3 a$ & $93 \%^{a}$ \\
\hline 2 & $3,4-\left(-\mathrm{OCH}_{2} \mathrm{O}-\right) 3 \mathbf{b}$ & $98 \%$ \\
\hline 3 & 2-OMe $3 \mathrm{c}$ & $96 \%^{b}$ \\
\hline 4 & 4-SMe 3d & $97 \%$ \\
\hline 5 & $4-\mathrm{CN} 3 e$ & $93 \%$ \\
\hline 6 & $4-\mathrm{CHO} 3 f$ & $89 \%$ \\
\hline 7 & $4-\mathrm{NO}_{2} \quad 3 \mathbf{g}$ & $86 \%$ \\
\hline 8 & $2-\mathrm{NO}_{2} 3 \mathrm{~h}$ & $81 \%$ \\
\hline 9 & $2-\mathrm{CF}_{3} 3 \mathbf{i}$ & $82 \%$ \\
\hline 10 & $2-13 j$ & $88 \%$ \\
\hline 11 & $2,3,5,6-\left(\mathrm{CH}_{3}\right)_{4} 3 \mathbf{k}$ & $90 \%$ \\
\hline 12 & $Y=H \quad 31$ & $89 \%$ \\
\hline 13 & $\mathrm{CH}_{3} 3 \mathrm{~m}$ & $91 \%$ \\
\hline 14 & & $76 \%$ \\
\hline 15 & $\mathrm{EtO}$ & $98 \%$ \\
\hline 16 & & $96 \%^{c}$ \\
\hline
\end{tabular}
a) $1 \mathrm{~g}$ scale. b) 0.2 equiv. $\mathrm{K}_{2} \mathrm{CO}_{3}$ used as catalyst.
c) 0.4 equiv. $\mathrm{KHCO}_{3}$ used as catalyst.

The mild reaction conditions are highlighted by formation of 30 in $98 \%$ yield; no transesterification of the ethyl ester with $\mathrm{MeOH}$ was observed (entry 15). To determine whether even less basic conditions promote the reaction on useful synthetic scale, methylation of $2 \mathrm{p}$ was investigated with $\mathrm{KHCO}_{3}$ (entry 16). $\alpha, \beta$-Unsaturated ester $3 p$ was isolated in $96 \%$ yield, confirming that bicarbonate can effectively catalyze the esterification.

Although significant racemization has previously been observed in DBU-mediated methylation reactions using DMC, ${ }^{21}$ we hypothesized that epimerizable stereocenters might be compatible with our mild, bicarbonate-catalyzed method. R-Ibuprofen (2q), which might epimerize via an enolate intermediate, was methylated in $87 \%$ yield with high retention of stereochemistry (Table 3 , entry 1 ). 
Given the importance of reactions to modify amino acids and peptides without loss of stereochemistry, amino acid substrates were also investigated. ${ }^{36}$ Methylated N-Boc-lle (3r) was obtained as a single observable diastereomer, while N-Boc-Phe (2s) was methylated with a 7\% decrease in enantiomeric ratio (Table 3, entries 2-3). Taken together, the syntheses of enantioenriched 3q-3s suggest that bicarbonatecatalyzed methylation is suitable even for epimerizable substrates.

\section{Table 3. Methylation with Conservation of Stereochemistry.}

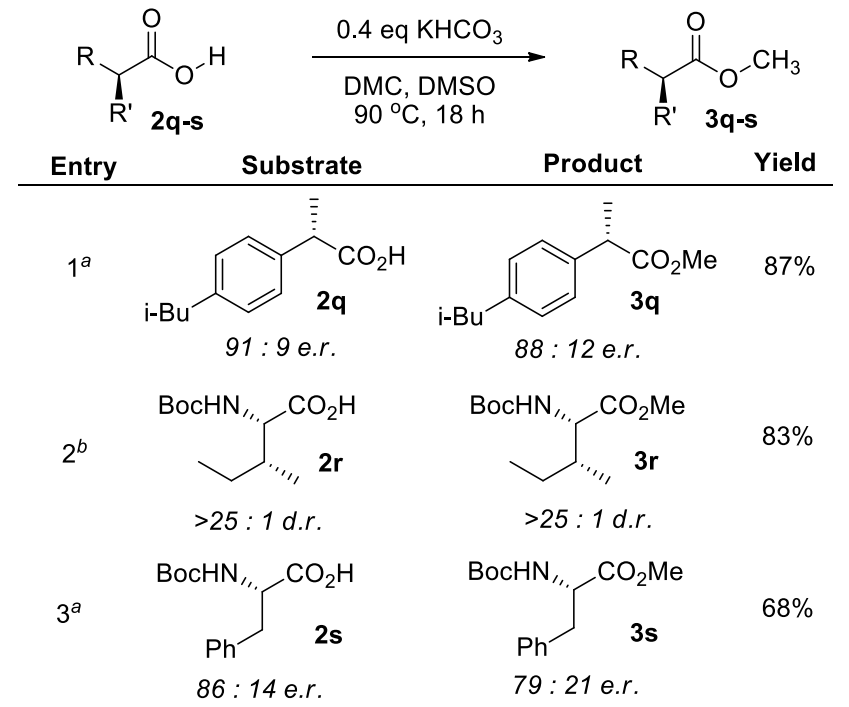

a) Enantiomeric ratio determined by polarimetry.

b) Diastereomeric ratio determined by ${ }^{1} \mathrm{H}$ NMR.

In previous methylations with DMC, chemoselectivity for esterification has been difficult to achieve in substrates bearing both carboxylic acid and phenol functional groups. Although zeolite catalysts displayed promising selectivity, ${ }^{26}$ product mixtures are often observed. ${ }^{24,37-38}$ Bifunctional substrate $\mathbf{4}$ was therefore investigated in reactions catalyzed by both potassium carbonate and potassium bicarbonate (Scheme 1). Regardless of the catalyst used, esterification product $\mathbf{5}$ was obtained in synthetically useful yield. Only trace $(<5 \%)$ etherification of the phenol was evident by ${ }^{1} \mathrm{H}$ NMR analysis of the crude reaction mixture, demonstrating high chemoselectivity for esterification.

The promising chemoselectivity observed with $\mathbf{4}$ suggested that the reaction should be applicable to densely functionalized substrates, such as 6 (Scheme 1). Under the standard reaction conditions with $\mathrm{KHCO}_{3}$, only the carboxylic acid in $\mathbf{6}$ was methylated; no reaction of the other potentially nucleophilic 
moieties was observed. Methyl ester 7, which has potential application as a component in sunscreens, ${ }^{39}$ was isolated in $92 \%$ yield, further demonstrating the compatibility of this method with relatively complex, useful small molecules.

\section{Scheme 1. Chemoselective Esterification.}

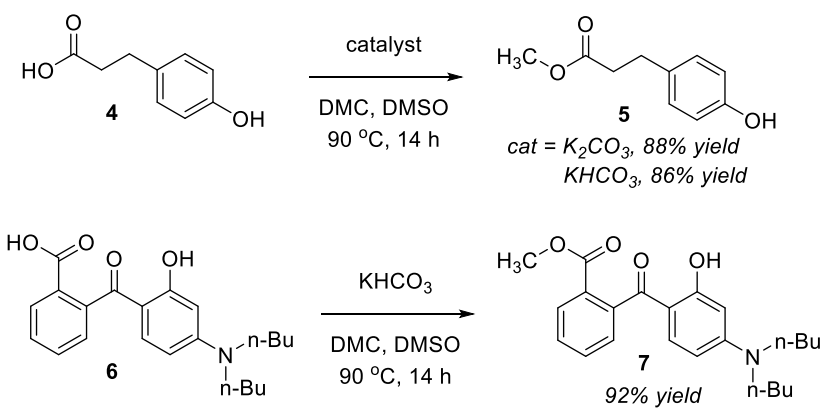

The mechanism of esterification with DMC in the absence of nucleophilic amine catalysts such as DBU and DABCO is unclear. ${ }^{22-27}$ Practical similarities between our carbonate-catalyzed reaction and Shieh's DBU-mediated methylation suggest possible mechanistic parallels. ${ }^{20}$ Both proceed at $90{ }^{\circ} \mathrm{C}$ with comparable reaction times. The DBU reaction is proposed to proceed via a $\mathrm{N}$-carbomethoxy ammonium intermediate formed from $\mathrm{DMC}$ and $\mathrm{DBU} \cdot{ }^{20,30} \mathrm{~A}$ similarly cationic activated intermediate is unlikely to form under the carbonate conditions.

Based on the proposed mechanism for DBU-mediated methylation, ${ }^{30}$ we hypothesize that $\mathrm{DMC}$ is activated prior to the methylation step. Since activated covalent adducts of catalysts such as $\mathrm{KOH}$ and $\mathrm{K}_{2} \mathrm{CO}_{3}$ with $\mathrm{DMC}$ are unlikely, we propose the formation of carbonic carboxylic anhydride 8 by reaction of the substrate (2a) with DMC (Scheme 2). ${ }^{40}$ Direct methylation of carboxylic acids with unactivated DMC is also possible, but is less consistent with studies of the DBU-mediated methylation. ${ }^{30}$

There are two likely general mechanisms for ester formation from 8: carbonyl substitution by $\mathrm{MeOH}$ liberated from DMC (Scheme 2, path a) or direct transfer of a methyl group from DMC to the carboxylate oxygen (Scheme 2, path b). Notably, path b encompasses several possibilities, including intramolecular excision of $\mathrm{CO}_{2}$ from $\mathbf{8}$ and intermolecular $\mathrm{S}_{\mathrm{N}} 2$-type methyl transfer from $\mathbf{8}$ to a second molecule of $\mathbf{2 a}{ }^{40}$ Given the observed reactivity of $\mathbf{4}$ and $\mathbf{6}$, we initially favored path a, but undertook further investigation. 
To differentiate between paths $\mathrm{a}$ and $\mathrm{b}$, an isotope-labeling experiment was performed with doubly ${ }^{18} \mathrm{O}-$ labeled benzoic acid $\left(\left[{ }^{18} \mathrm{O}\right]_{2}-2 \mathrm{a}\right.$, Scheme 2$)$. The product mass corresponding to doubly-labeled $\left[{ }^{18} \mathrm{O}\right]_{2}-3 a$ was observed by GCMS, indicating that both oxygen atoms originally present in $\left[{ }^{18} \mathrm{O}\right]_{2}-2 \mathbf{a}$ are retained in the product (see Experimental Section).

Scheme 2. Isotope-Labeling Suggests Methyl Transfer

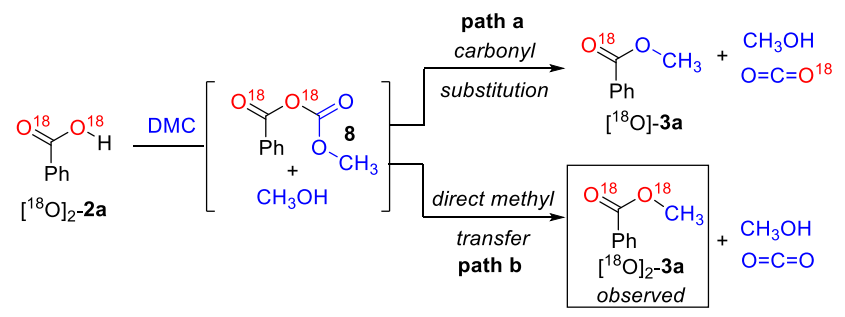

This result supports path $b$, a direct methyl transfer from DMC to the substrate, and is inconsistent with path a. An $\mathrm{S}_{\mathrm{N} 2}$-type methyl transfer from unactivated DMC (rather than $\mathbf{8}$ ) to deprotonated $\mathbf{2 a}$ is also consistent with formation of $\left[{ }^{18} \mathrm{O}\right]_{2}-2 a$. To the best of our knowledge, this is the first conclusive evidence for direct methyl transfer in esterification with DMC absent a nucleophilic amine catalyst such as DBU. Overall, the labeling study suggests that DMC is behaving like diazomethane and other electrophilic methyl transfer reagents, rather than as a source of $\mathrm{MeOH}$ for a Fisher-type esterification.

In conclusion, a general base-catalyzed methylation of carboxylic acids, including those with electronwithdrawing groups, unprotected phenols, and epimerizable stereocenters, has been developed. The mild reaction conditions, formation of only $\mathrm{MeOH}$ and $\mathrm{CO}_{2}$ as reaction byproducts, and use of inexpensive carbonate salts as catalysts suggest that methyl transfer from DMC should be considered as a viable alternative to common methods for the synthesis of methyl esters. 


\section{Experimental Section.}

General Information. Unless otherwise noted, all reagents were obtained commercially and used without further purification. TLC analysis of reaction mixtures was performed on silica gel 60 F254 TLC plates using $\mathrm{KMnO}_{4}$ stain and UV light to visualize the reaction components. Column chromatography was carried out on $60 \AA, 40-63 \mu \mathrm{m}$ silica gel using mixtures of ethyl acetate and hexanes as eluent.

GC-MS quantitation of reaction progress was accomplished by end-point analysis using dimethyl pimelate as an internal standard. A J\&W DB5-ms GC capillary column (0.25 mm x $30 \mathrm{~m}, 0.25 \mu \mathrm{M}$ film thickness) was used. ${ }^{1} \mathrm{H}$ and ${ }^{13} \mathrm{C}$ NMR spectra were referenced to chloroform and recorded at room temperature unless otherwise noted. Optical rotation was determined at $589 \mathrm{~nm}$. Enantiomeric ratios of both carboxylic acid starting materials and methyl ester products were determined by comparing observed optical rotations with previous literature reports (see Supporting Information, Table S-1).

Methyl benzoate (2a, CAS Registry: 93-58-3). To a $250 \mathrm{~mL}$ round-bottom flask equipped with magnetic stir bar, reflux condenser, and nitrogen inlet was added benzoic acid (2a) (1.00 g, 8.19 mmol, 1.0 equiv), DMSO (40 mL), and dimethylcarbonate (1) $(13.8 \mathrm{~mL}, 160 \mathrm{mmol}, 20.0$ equiv). To the resulting solution was added potassium carbonate $\left(0.453 \mathrm{~g}, 3.28 \mathrm{mmol}, 0.4\right.$ equiv). The reaction mixture was stirred at $90^{\circ} \mathrm{C}$ for 16 hours and then cooled to room temperature. Ethyl acetate $(50 \mathrm{~mL})$ was added and the mixture was washed with water $(2 \times 50 \mathrm{~mL})$ and brine $(1 \times 50 \mathrm{~mL})$. The organic layer was dried with magnesium sulfate, filtered, and concentrated to yield methyl benzoate (3a) as a clear liquid (1.043 $\mathrm{g}, 93 \%$ yield). The spectral data were consistent with reported values. ${ }^{41}{ }^{1} \mathrm{H}$ NMR $\left(\mathrm{CDCl}_{3}, 300 \mathrm{MHz}\right) \delta 8.06(\mathrm{~m}, 2 \mathrm{H}), 7.57(\mathrm{~m}$, $1 \mathrm{H}), 7.45$ (m, $2 \mathrm{H}), 3.94(\mathrm{~s}, 3 \mathrm{H})$.

General procedure for the methylation of carboxylic acids (2b-2s) with DMC. To a $25 \mathrm{~mL}$ round bottom flask equipped with magnetic stir bar, reflux condenser, and nitrogen inlet was added the appropriate carboxylic acid ( 100 mg, 1 equiv.), DMSO (0.2 M substrate concentration) and DMC (20 equiv.). To the resulting solution was added potassium carbonate ( 0.4 equiv.) in one portion. The reaction mixture was magnetically stirred and heated to $90^{\circ} \mathrm{C}$ for 16 hours. After cooling to room temperature, the reaction was diluted with ethyl acetate $(15 \mathrm{~mL})$, washed with water $(2 \times 10 \mathrm{~mL})$ and brine $(1 \times 10 \mathrm{~mL})$, and dried with magnesium sulfate. Unless otherwise noted, pure methyl ester was obtained upon removal of solvent. 
Methyl piperonylate (3b, CAS Registry: 326-56-7). Carboxylic acid 2b (100 mg, $0.60 \mathrm{mmol})$ was reacted according to the general procedure except that sodium sulfate replaced magnesium sulfate as the drying agent. Methyl ester 3b was isolated as a white solid (106 mg, 98\% yield). The spectral data were consistent with reported values. ${ }^{42}{ }^{1} \mathrm{H}$ NMR $\left(\mathrm{CDCl}_{3}, 300 \mathrm{MHz}\right) 7.64(\mathrm{dd}, 1 \mathrm{H}, \mathrm{J}=8.2,1.7 \mathrm{~Hz}), 7.47(\mathrm{~d}, 1 \mathrm{H}$, $J=1.7 \mathrm{~Hz}), 6.85(\mathrm{~d}, 1 \mathrm{H}, J=8.2 \mathrm{~Hz}), 6.03(\mathrm{~s}, 2 \mathrm{H}), 3.88(\mathrm{~s}, 3 \mathrm{H})$.

Methyl 2-methoxybenzoate (3c, CAS Registry: 606-45-1). Carboxylic acid 2c (100 mg, $0.66 \mathrm{mmol}$ ) was reacted according to a modified general procedure. A decreased catalyst loading of potassium carbonate (18 $\mathrm{mg}, 0.13 \mathrm{mmol}, 0.2$ equiv) was used. After workup, the crude reaction mixture was further purified by column chromatography (9:1 hexanes:ethyl acetate eluent). Ester $\mathbf{3 c}$ was isolated as a yellow oil (105 $\mathrm{mg}, 96 \%$ yield). The spectral data were consistent with reported values. ${ }^{43}{ }^{1} \mathrm{H} \mathrm{NMR}\left(\mathrm{CDCl}_{3}, 300 \mathrm{MHz}\right) \delta$ 7.79 (dd, $1 \mathrm{H}, J=1.7,7.9 \mathrm{~Hz}), 7.46(\mathrm{~m}, 1 \mathrm{H}), 6.97(\mathrm{~m}, 2 \mathrm{H}), 3.89(\mathrm{~s}, 3 \mathrm{H}), 3.88(\mathrm{~s}, 3 \mathrm{H})$.

Methyl 4-(methylthio)benzoate (3d, CAS Registry: 3795-79-7). Carboxylic acid 2d (150 mg, 0.89 mmol) was reacted according to the general procedure. Methyl ester $\mathbf{3 d}$ was isolated as an off-white solid (157 $\mathrm{mg}, 97 \%$ yield). The spectral data were consistent with reported values. ${ }^{44}{ }^{1} \mathrm{H} \mathrm{NMR}\left(\mathrm{CDCl}_{3}, 300 \mathrm{MHz}\right) \delta$ $7.95(\mathrm{~d}, 2 \mathrm{H}, J=8.7 \mathrm{~Hz}), 7.26$ (d, $2 \mathrm{H}, J=8.7 \mathrm{~Hz}), 3.92(\mathrm{~s}, 3 \mathrm{H}), 2.53$ (s, $3 \mathrm{H})$.

Methyl 4-cyanobenzoate (3e, CAS Registry: 1129-35-7). Carboxylic acid 2e (100 mg, $0.68 \mathrm{mmol}$ ) was reacted according to the general procedure except that sodium sulfate replaced magnesium sulfate as the drying agent. Methyl ester $3 e$ was isolated as a white solid (102 mg, 93\% yield). The spectral data were consistent with reported values. ${ }^{43}{ }^{1} \mathrm{H} \mathrm{NMR}\left(\mathrm{CDCl}_{3}, 300 \mathrm{MHz}\right) 8.14(\mathrm{~d}, 2 \mathrm{H}, J=8.2 \mathrm{~Hz}), 7.77(\mathrm{~d}, 2 \mathrm{H}$, $J=8.2 \mathrm{~Hz}), 3.97(\mathrm{~s}, 3 \mathrm{H})$.

Methyl 4-formylbenzoate (3f, CAS Registry: 1571-08-0). Carboxylic acid 2f (101 mg, $0.67 \mathrm{mmol}$ ) was reacted according to the general procedure. Methyl ester $\mathbf{3 f}$ was isolated as an off-white solid (98 $\mathrm{mg}$, $89 \%$ yield). The spectral data were consistent with reported values. ${ }^{44}{ }^{1} \mathrm{H}$ NMR $\left(\mathrm{CDCl}_{3}, 500 \mathrm{MHz}\right) \delta 10.10$ (s, $1 \mathrm{H}), 8.19(\mathrm{~d}, 2 \mathrm{H}, J=8.3 \mathrm{~Hz}), 7.95(\mathrm{~d}, 2 \mathrm{H}, J=8.4 \mathrm{~Hz}), 3.96(\mathrm{~s}, 3 \mathrm{H})$.

Methyl 4-nitrobenzoate (3g, CAS Registry: 619-50-1). Carboxylic acid $\mathbf{2 g}$ (100 mg, $0.60 \mathrm{mmol}$ ) was reacted according to the general procedure. Methyl ester $\mathbf{3 g}$ was isolated as a pale yellow solid (93 $\mathbf{m g}$, $86 \%$ yield). The spectral data were consistent with report values. ${ }^{45}{ }^{1} \mathrm{H} \mathrm{NMR}\left(\mathrm{CDCl}_{3}, 300 \mathrm{MHz}\right) \delta 8.3(\mathrm{~d}, 2$ $\mathrm{H}, J=8.9 \mathrm{~Hz}), 8.2(\mathrm{~d}, 2 \mathrm{H}, J=9.0 \mathrm{~Hz}), 4.0(\mathrm{~s}, 3 \mathrm{H})$. 
Methyl 2-nitrobenzoate (3h, CAS Registry: 606-27-9). Carboxylic acid 2h (134 mg, $0.80 \mathrm{mmol}$ ) was reacted according to the general procedure. Methyl ester $\mathbf{3 h}$ was isolated as a white solid $(118 \mathrm{mg}, 81 \%$ yield). The spectral data were consistent with reported values. ${ }^{43}{ }^{1} \mathrm{H} \mathrm{NMR}\left(\mathrm{CDCl}_{3}, 300 \mathrm{MHz}\right) \delta 7.81(\mathrm{~m}, 1$ H), 7.8-7.6 (m, 3 H), $3.92(\mathrm{~s}, 3 \mathrm{H})$.

Methyl 2-(trifluoromethyl)benzoate (3i, CAS Registry: 344-96-7). Carboxylic acid 2i (100 mg, 0.53 mmol) was reacted according to the general procedure except that sodium sulfate replaced magnesium sulfate as the drying agent. Methyl ester $\mathbf{3} \mathbf{i}$ was isolated as a white solid ( $88 \mathrm{mg}, 82 \%$ yield). The spectral data were consistent with reported values. ${ }^{41}{ }^{1} \mathrm{H} \mathrm{NMR}\left(\mathrm{CDCl}_{3}, 300 \mathrm{MHz}\right) 7.81(\mathrm{~m}, 2 \mathrm{H}), 7.62(\mathrm{~m}, 2 \mathrm{H}), 3.95$ $(\mathrm{s}, 3 \mathrm{H})$

Methyl 2-iodobenzoate (3j, CAS Registry: 610-97-9). Carboxylic acid 2j (103 mg, $0.415 \mathrm{mmol}$ ) was reacted according to the general procedure. Methyl ester $\mathbf{3 j}$ was isolated as a clear oil $(96 \mathbf{m g}, 88 \%$ yield). The spectral data were consistent with reported values. ${ }^{43}{ }^{1} \mathrm{H} \mathrm{NMR}\left(\mathrm{CDCl}_{3}, 300 \mathrm{MHz}\right) \delta 8.01$ (dd, 1 $\mathrm{H}, J=8.0,1.0 \mathrm{~Hz}), 7.82(\mathrm{dd}, 1 \mathrm{H}, J=7.8,1.7 \mathrm{~Hz}), 7.41(\mathrm{dt}, 1 \mathrm{H}, J=7.7,1.2), 7.16(\mathrm{dt}, 1 \mathrm{H}, J=7.7,1.7$ $\mathrm{Hz}), 3.94(\mathrm{~s}, 3 \mathrm{H})$.

2,3,5,6-tetramethyl-benzoic acid methyl ester (3k, CAS Registry: 22524-51-2). Carboxylic acid 2k (100 $\mathrm{mg}, 0.56 \mathrm{mmol}$ ) was reacted according to the general procedure. After workup, the crude reaction mixture was further purified by column chromatography (50:1 hexanes:ethyl acetate eluent). Methyl ester 3k was isolated as a white solid (97 mg, 90\% yield). The spectral data were consistent with reported values. ${ }^{46}{ }^{1} \mathrm{H}$ $\operatorname{NMR}\left(\mathrm{CDCl}_{3}, 300 \mathrm{MHz}\right) \delta 7.02(\mathrm{~s}, 1 \mathrm{H}), 3.96(\mathrm{~s}, 3 \mathrm{H}), 2.25(\mathrm{~s}, 6 \mathrm{H}), 2.18(\mathrm{~s}, 6 \mathrm{H})$.

Methyl phenylacetate (3I, CAS Registry: 101-41-7). Carboxylic acid 2l (112 mg, $0.82 \mathrm{mmol}$ ) was reacted according to the general procedure. Methyl ester $\mathbf{3 l}$ was isolated as a white solid (110 $\mathrm{mg}, 89 \%$ yield). The spectral data were consistent with reported values. ${ }^{47}{ }^{1} \mathrm{H} \mathrm{NMR}\left(\mathrm{CDCl}_{3}, 300 \mathrm{MHz}\right) \delta$ 7.5-7.2 $(\mathrm{m}, 5 \mathrm{H})$, $3.73(\mathrm{~s}, 3 \mathrm{H}), 3.67$ (s, $2 \mathrm{H})$.

2-Methyl-2-phenylpropionate methyl ester (3m, CAS Registry: 57625-74-8). Carboxylic acid 2m (100 $\mathrm{mg}, 0.61 \mathrm{mmol}$ ) was reacted according to the general procedure. Methyl ester $3 \mathrm{~m}$ was isolated as a white solid (99 mg, 91\% yield). The spectral data were consistent with reported values. ${ }^{48}{ }^{1} \mathrm{H} \mathrm{NMR}\left(\mathrm{CDCl}_{3}, 300\right.$ $\mathrm{MHz}) \delta$ 7.5-7.2 (m, $5 \mathrm{H}), 3.69(\mathrm{~s}, 3 \mathrm{H}), 1.64(\mathrm{~s}, 6 \mathrm{H})$. 
N-(tert-Butoxycarbonyl)glycine methyl ester (3n, CAS Registry: 31954-27-5). Carboxylic acid 2n (100 $\mathrm{mg}, 0.57 \mathrm{mmol}$ ) was reacted according to the general procedure. Methyl ester $\mathbf{3 n}$ was isolated as a clear, colorless oil (82 mg, 76\% yield). The spectral data were consistent with reported values. ${ }^{45}{ }^{1} \mathrm{H}$ NMR $\left(\mathrm{CDCl}_{3}, 300 \mathrm{MHz}\right) \delta 5.3(\mathrm{bs}, 1 \mathrm{H}), 3.9(\mathrm{~d}, 2 \mathrm{H}, J=5.6 \mathrm{~Hz}), 3.74(\mathrm{~s}, 3 \mathrm{H}), 1.45(\mathrm{~s}, 9 \mathrm{H})$.

Ethyl methyl adipate (3o, CAS Registry: 18891-13-9). Carboxylic acid 20 (98 mg, $0.56 \mathrm{mmol}$ ) was reacted according to the general procedure. After workup, the crude reaction mixture was further purified by column chromatography (19:1 hexanes:ethyl acetate eluent). Methyl ester 3o was isolated as a clear oil (103 mg, 98\% yield). The spectral data were consistent with reported values. ${ }^{49}{ }^{1} \mathrm{H} \mathrm{NMR}\left(\mathrm{CDCl}_{3}, 300\right.$ $\mathrm{MHz}) \delta 4.08(2 \mathrm{H}, \mathrm{q}, J=7.2 \mathrm{~Hz}), 3.62(\mathrm{~s}, 3 \mathrm{H}), 2.28(\mathrm{~m}, 4 \mathrm{H}), 1.62(\mathrm{~m}, 4 \mathrm{H}), 1.21(\mathrm{t}, 3 \mathrm{H}, J=7.2 \mathrm{~Hz})$.

Methyl cinnamate (3p, CAS Registry: 103-26-4). Carboxylic acid 2p (100 mg, $0.68 \mathrm{mmol})$ was reacted according to a modified general procedure. Potassium bicarbonate $(27 \mathrm{mg}, 0.27 \mathrm{mmol}, 0.4$ equiv.) replaced potassium carbonate as the catalyst. Methyl ester $3 p$ was isolated as a white solid (105 mg, $96 \%$ yield). The spectral data were consistent with reported values. ${ }^{45}{ }^{1} \mathrm{H} \mathrm{NMR}\left(\mathrm{CDCl}_{3}, 300 \mathrm{MHz}\right) \delta 7.7$ (d, $1 \mathrm{H}, J=16.0 \mathrm{~Hz}), 7.5(\mathrm{~m}, 2 \mathrm{H}), 7.4(\mathrm{~m}, 3 \mathrm{H}), 6.5(\mathrm{~d}, 1 \mathrm{H}, J=16.0 \mathrm{~Hz}), 3.8(\mathrm{~s}, 3 \mathrm{H})$.

(S)-ibuprofen methyl ester (3q, CAS Registry: 81576-55-8). Carboxylic acid 2q (100 mg, 0.49 mmol, 91:9 e.r.) was reacted according to a modified general procedure. Potassium bicarbonate $(19 \mathrm{mg}, 0.19$ mmol, 0.4 equiv.) replaced potassium carbonate as the catalyst. After workup, the crude reaction mixture was further purified by column chromatography (50:1 hexanes: ethyl acetate eluent). Methyl ester $\mathbf{3 q}$ was isolated as a white solid (93 mg, 87\% yield, 88:12 e.r.). ${ }^{1} \mathrm{H}$ NMR $\left(\mathrm{CDCl}_{3}, 300 \mathrm{MHz}\right) \delta 7.2(\mathrm{~d}, 2 \mathrm{H}, J=8.0$ Hz), 7.1 (d, $2 \mathrm{H}, J=8.0 \mathrm{~Hz}$ ), $3.8(\mathrm{q}, 1 \mathrm{H}, J=7.2 \mathrm{~Hz}$ ), 3.7 (s, $3 \mathrm{H}), 2.5(\mathrm{~d}, 2 \mathrm{H}, J=7.3 \mathrm{~Hz}$ ), 1.9 (nonet, $1 \mathrm{H}$, $J=6.8 \mathrm{~Hz}), 1.5(\mathrm{~d}, 3 \mathrm{H}, J=7.2 \mathrm{~Hz}), 0.9(\mathrm{~d}, 6 \mathrm{H}, J=6.6 \mathrm{~Hz})$. Optical rotation (see Table S-1): [a] $\mathrm{D}_{25}=$ $+49.4\left(c 1.00, \mathrm{CHCl}_{3}\right)$.

N-(tert-butyloxycarbonyl)-L-isoleucine methyl ester (3r, CAS Registry: 17901-01-8). Carboxylic acid 2r (125 mg, $0.54 \mathrm{mmol},>25: 1$ d.r.) was reacted according to a modified general procedure. Potassium bicarbonate (22 mg, $0.22 \mathrm{mmol}, 0.4$ equiv.) replaced potassium carbonate as the catalyst. Methyl ester $3 \mathbf{r}$ was isolated as a clear, colorless oil (110 mg, $83 \%$ yield, $>25: 1$ d.r.). The spectral data indicated the presence of a single diastereomer and were consistent with reported values. ${ }^{50} \mathrm{NMR}$ data was acquired at elevated temperature so that peaks arising from hindered rotation around the amide bond coalesced. ${ }^{1} \mathrm{H}$ 
$\operatorname{NMR}\left(\mathrm{CDCl}_{3}, 300 \mathrm{MHz}, 47^{\circ} \mathrm{C}\right) \delta 5.0(\mathrm{bs}, 1 \mathrm{H}), 4.2(\mathrm{bs}, 1 \mathrm{H}), 3.7(\mathrm{~s}, 3 \mathrm{H}), 1.8(\mathrm{bs}, 1 \mathrm{H}), 1.5-1.3(\mathrm{~m}, 10 \mathrm{H})$, 1.2-1.0 (m, $1 \mathrm{H}), 0.9-0.8(\mathrm{~m}, 6 \mathrm{H})$.

N-(tert-butyloxycarbonyl)-L-phenylalanine methyl ester (3s, CAS Registry: 51987-73-6). Carboxylic acid 2 s (100 mg, $0.377 \mathrm{mmol}, 86: 14$ e.r) was reacted according to a modified general procedure. Potassium bicarbonate (15 mg, $0.15 \mathrm{mmol}, 0.4$ equiv.) replaced potassium carbonate as the catalyst. After workup, the crude reaction mixture was further purified by column chromatography (19:1 hexanes: ethyl acetate eluent). Methyl ester $3 \mathbf{s}$ was isolated as a white solid (72 mg, 68\% yield, 79:21 e.r.). NMR data was acquired at elevated temperature so that peaks arising from hindered rotation around the amide bond coalesced. ${ }^{1} \mathrm{H}$ NMR $\left(\mathrm{CDCl}_{3}, 300 \mathrm{MHz}, 52{ }^{\circ} \mathrm{C}\right) \delta$ 7.2-7.3 $(\mathrm{m}, 3 \mathrm{H}), 7.1(\mathrm{~m}, 2 \mathrm{H}), 5.0(\mathrm{bs}, 1 \mathrm{H}), 4.6(\mathrm{bs}$, $1 \mathrm{H}), 3.7(\mathrm{~s}, 3 \mathrm{H}), 3.1(\mathrm{~m}, 2 \mathrm{H}), 1.4(\mathrm{~s}, 9 \mathrm{H})$. Optical rotation (see Table S-1): $[\mathrm{\alpha}]^{\mathrm{D}_{25}}=+35.0(\mathrm{c} 1.00$, $\left.\mathrm{CHCl}_{3}\right)$.

Methyl 3-(4-hydroxyphenyl)propionate (5, CAS Registry:5597-50-2). Carboxylic acid 4 (100 mg, 0.6 $\mathrm{mmol}$ ) was reacted according to the general procedure using either potassium carbonate (33 $\mathrm{mg}, 0.24$ mmol, 0.4 equiv.) or potassium bicarbonate $(24 \mathrm{mg}, 0.15 \mathrm{mmol}, 0.4$ equiv.) as the catalyst. After 14 hours, the reactions were subjected to the standard workup. The crude reaction mixtures were further purified by column chromatography ( $9: 1$ hexanes:ethyl acetate eluent). In the potassium carbonatecatalyzed case, 5 was isolated as a clear oil (95 mg, 88\% yield). In the potassium bicarbonate-catalyzed case, 5 was isolated as a clear oil (94 mg, 86\% yield). Spectral data were consistent with reported values. ${ }^{51}{ }^{1} \mathrm{H} \mathrm{NMR}\left(\mathrm{CDCl}_{3}, 300 \mathrm{MHz}\right) \delta 7.05(\mathrm{~d}, 2 \mathrm{H}, J=8.4 \mathrm{~Hz}), 6.79(\mathrm{~d}, 2 \mathrm{H}, J=8.4 \mathrm{~Hz}), 6.68(\mathrm{bs}, 1 \mathrm{H})$, 3.70 (s, $3 \mathrm{H}), 2.90$ (t, $2 \mathrm{H}, J=7.5 \mathrm{~Hz}), 2.64$ (t, $2 \mathrm{H}, J=7.5 \mathrm{~Hz})$.

Methyl 2-(4-dibutylamino-2-hydroxybenzoyl)benzoate (7, CAS Registry: 302776-69-8). Carboxylic acid 6 (100 mg, $0.27 \mathrm{mmol}$ ) was reacted according to a modified general procedure. Potassium bicarbonate (11 mg, $0.11 \mathrm{mmol}, 0.4$ equiv.) replaced potassium carbonate as the catalyst. After workup, the crude reaction mixture was further purified by column chromatography (19:1 hexanes:ethyl acetate eluent). Methyl ester 7 was isolated as a yellow oil (95 mg, 92\% yield). Spectral data has not previously been reported for $7 .{ }^{1} \mathrm{H} \mathrm{NMR}\left(\mathrm{CDCl}_{3}, 300 \mathrm{MHz}\right) \delta 12.63(\mathrm{~s}, 1 \mathrm{H}), 8.05(\mathrm{dd}, 1 \mathrm{H}, J=7.2,1.2 \mathrm{~Hz}), 7.60$ (td, $1 \mathrm{H}, J=7.2,1.2 \mathrm{~Hz}), 7.52(\mathrm{td}, 1 \mathrm{H}, J=7.5,1.5 \mathrm{~Hz}), 7.37$ (dd, $1 \mathrm{H}, J=7.2,1.2 \mathrm{~Hz}), 6.89(\mathrm{~d}, 1 \mathrm{H}, J=9.0$ $\mathrm{Hz}$ ), $6.14(\mathrm{~d}, 1 \mathrm{H}, J=2.4 \mathrm{~Hz}), 6.04(\mathrm{dd}, 1 \mathrm{H}, J=9.0,2.4 \mathrm{~Hz}), 3.75(\mathrm{~s}, 3 \mathrm{H}),, 3.30(\mathrm{t}, 4 \mathrm{H}, J=7.5 \mathrm{~Hz}), 1.59$ 
(m, $4 \mathrm{H}), 1.34(\mathrm{~m}, 4 \mathrm{H}), 0.96$ (t, $6 \mathrm{H}, J=7.5 \mathrm{~Hz}) .{ }^{13} \mathrm{C} \mathrm{NMR}(75 \mathrm{MHz}) \delta 198.5,166.5,165.3,154.3,140.8$, $134.4,132.1$, 130.2, 129.1, 128.8, 127.9, 109.9, 103.9, 97.3, 52.3, 50.9, 29.4, 20.2, 13.9. HRMS (EI) m/z calcd for $\mathrm{C}_{23} \mathrm{H}_{29} \mathrm{NO}_{4} 383.2097$, found 383.2088.

Procedure and GCMS data for the Isotope-Labeling Experiment. $\left[{ }^{18} \mathrm{O}\right]_{2}-2 a$ was prepared from benzotrichloride and ${ }^{18} \mathrm{O}$-water (97\%, Cambridge Isotope) according to published procedure. ${ }^{52}$ The ${ }^{1} \mathrm{H}$ NMR spectral data were consistent with the values observed for $2 a$. GC-MS $m / z$ (\% relative intensity, ion): $126.2(81 \%, M), 107.2\left(100 \%, M-\left({ }^{18} \mathrm{OH}\right)\right), 77.1\left(94 \%, M-\left(C\left[{ }^{18} \mathrm{O}\right]_{2} \mathrm{H}\right)\right)$. The molecular ion peak corresponding to $\left[{ }^{18} \mathrm{O}\right]-2 \mathrm{a}$ was also identified: $124.1(3.6 \%, \mathrm{M})$. The molecular ion peak corresponding to unlabeled 2a was also identified: $122.1(1.3 \%, \mathrm{M})$. The percentage of ${ }^{18} \mathrm{O}$ in synthetic $\left[{ }^{18} \mathrm{O}\right]_{2}-2 \mathrm{a}$ was therefore calculated to be $96.5 \%$.

$\left[{ }^{18} \mathrm{O}\right]_{2}-2 \mathrm{a}$ was reacted with $\mathrm{DMC}$ according to the general methylation procedure. Aliquots were taken from the reaction at $\mathrm{T}=6 \mathrm{~h}$ and $24 \mathrm{~h}$ and analyzed by GCMS.

$\mathrm{T}=6 \mathrm{~h}$ aliquot. $\left[{ }^{18} \mathrm{O}\right] 2-3 \mathrm{a}$ identified by GC-MS m/z (\% relative intensity, ion): $140.2(32 \%, \mathrm{M}), 107.2$ $\left(100 \%, \mathrm{M}-\left({ }^{18} \mathrm{OCH}_{3}\right)\right), 77.1\left(78 \%, \mathrm{M}-\left(\mathrm{C}^{18} \mathrm{O}_{2} \mathrm{CH}_{3}\right)\right)$. The molecular ion peak corresponding to $\left[{ }^{18} \mathrm{O}\right]-3 \mathrm{a}$ was also identified: $138.2(1.3 \%, M)$. The molecular ion peak corresponding to unlabeled $\mathbf{3 a}$ was also identified: $136.2(0.1 \%, M)$. The calculated percentages of product formed are $95.8 \%\left[{ }^{18} \mathrm{O}\right]_{2}-3 \mathrm{a}, 3.9 \%$ $\left[{ }^{18} \mathrm{O}\right]-3 \mathrm{a}$, and $0.3 \% 3 \mathbf{3 a}$.

$\mathrm{T}=24 \mathrm{~h}$ aliquot. $\left[{ }^{18} \mathrm{O}\right]_{2}-3 \mathrm{a}$ identified by GC-MS $\mathrm{m} / \mathrm{z}$ (\% relative intensity, ion): $140.2(31 \%, \mathrm{M}), 107.2$ (100\%, M - $\left.\left({ }^{18} \mathrm{OCH}_{3}\right)\right), 77.1\left(77 \%, \mathrm{M}-\left(\mathrm{C}\left[{ }^{18} \mathrm{O}\right]_{2} \mathrm{CH}_{3}\right)\right)$. The molecular ion peak corresponding to $\left[{ }^{18} \mathrm{O}\right]-3 \mathrm{a}$ was also identified: $138.2(3.1 \%, M)$. The molecular ion peak corresponding to unlabeled 3a was also identified: $136.2(0.2 \%, M)$. The calculated percentages of product formed are $90.4 \%\left[{ }^{18} \mathrm{O}\right] 2-3 \mathrm{a}, 9.0 \%$ $\left[{ }^{18} \mathrm{O}\right]-3 \mathrm{a}$, and $0.6 \% 3 \mathbf{3}$.

Acknowledgment We gratefully acknowledge the donors of the American Chemical Society Petroleum Research Fund (\#52706-UNI1) for support of this research. Summer undergraduate research fellowships were provided by the Smith College Provost's Office (J.S.) and Science Center (Y.J., J.Z.). We thank Dr. Charles Amass (Smith College) for assistance with the GCMS, NMR spectrometers, and polarimeter. Mass Spectral data were obtained at the University of Massachusetts Mass Spectrometry Center. 
Supporting Information Available Optical rotation data and comparison with literature data for $\mathbf{2 q}, \mathbf{2 s}$,

3q, and 3s. Copies of ${ }^{1} \mathrm{H}$ NMR spectra for 2a-2s and $\mathbf{5}$. Copies of ${ }^{1} \mathrm{H}$ and ${ }^{13} \mathrm{C}$ NMR spectra for 7 . This

material is available free of charge via the Internet at http://pubs.acs.org.

(1) Rajapaksa, N. S.; McGowan, M. A.; Rienzo, M.; Jacobsen, E. N. Org. Lett. 2013, 15, 706.

(2) Mita, T.; Higuchi, Y.; Sato, Y. Chem. Eur. J. 2013, 19, 1123.

(3) Schrader, T. O.; Johnson, B. R.; Lopez, L.; Kasem, M.; Gharbaoui, T.; Sengupta, D.; Buzard, D.; Basmadjian, C.; Jones, R. M. Org. Lett. 2012, 14, 6306.

(4) Giordanengo, R.; Viel, S.; Hidalgo, M.; Allard-Breton, B.; Thevand, A.; Charles, L. Rapid Comm. Mass. Spec. 2010, 24, 1941.

(5) Otera, J.; Nishikido, J. Esterification: Methods, Reactions, and Applications, Second Edition; Wiley-VCH: Weinheim, 2010.

(6) Lamoureux, G.; Aguero, C. ARKIVOC 2009, 251.

(7) Kemsley, J. N. Chem. Eng. News 2011, 89, 15.

(8) Hite, M.; Rinehart, W.; Braun, W.; Peck, H. Am. Ind. Hyg. Assoc. J. 1979, 40, 600.

(9) Rippey, J. C. R.; Stallwood, M. I. Emerg. Med. J. 2005, 22, 878.

(10) Mileson, B. E.; Sweeney, L. M.; Gargas, M. L.; Kinzell, J. Inhal. Toxicol. 2009, 21, 583.

(11) Hodnett, N. S. Synlett 2003, 2095.

(12) Morandi, B.; Carreira, E. M. Science 2012, 335, 1471.

(13) Maurya, R. A.; Park, C. P.; Lee, J. H.; Kim, D.-P. Angew. Chem. Int. Ed. 2011, 50, 5952.

(14) Ye, L.; Cui, L.; Zhang, G.; Zhang, L. J. Am. Chem. Soc. 2010, 132, 3258 and references cited therein.

(15) Soleimani, E. Synlett 2007, 1625.

(16) For replacement of diazomethane in Arndt-Eistert synthesis, see: Wang, D.; Schwinden, M. D.; Radesca, L.;

Patel, B.; Kronenthal, D.; Huang, M-. H.; Nugent, W. A. J. Org. Chem. 2004, 69, 1629.

(17) For a review, see: Tundo, P.; Selva, M. Acc. Chem. Res. 2002, 35, 706.

(18) Tundo, P.; Rossi, L.; Loris, A. J. Org. Chem. 2005, 70, 2219.

(19) For a comparison of methylating reagents from a green chemistry perspective, see: Selva, M.; Perosa, A. Green Chem. 2008, 257.

(20) Shieh, W. -C.; Dell, S.; Repič, O. J. Org. Chem. 2002, 67, 2188.

(21) Shieh, W. -C.; Dell, S.; Repič, O. Tetrahedron Lett. 2002, 43, 5607.

(22) Chau, K. D. N.; Duus, F.; Le, T. N. Green Chem. Lett. Rev. 2013, 6, 89 and references cited therein.

(23) Caretto, A.; Perosa, A. ACS Sustainable Chem. Eng. 2013, 1, 989.

(24) Dhakshinamoorthy, A.; Sharmila, A.; Pitchumani, K. Chem. Eur. J. 2010, 16, 1128.

(25) Guerrero, L. R.; Rivero, I. R. ARKIVOC, 2008, 11, 295.

(26) Selva, M.; Tundo, P. J. Org. Chem. 2006, 71, 1464.

(27) Rajabi, F.; Saidi, M. R. Synth. Commun. 2004, 34, 4179.

(28) For enzymatic activation of DMC, see: Gharat, N.; Rathod, V. K. J. Mol. Catal. B 2013, 88, 36.

(29) For $\mathrm{H}_{2} \mathrm{SO}_{4}$-catalyzed methylation with DMC, see: Rekha, V. V.; Ramani, M. V.; Ratnamala, A.; Rupakalpana, V.; Subbaraju, G. V.; Satyanarayana, C.; Rao, C. S. Org. Proc. Res. Dev. 2009, 13, 769.

(30) For mechanistic studies, see: Carafa, M.; Mesto, E.; Quaranta, E. Eur. J. Org. Chem. 2011, 2458.

(31) For the use of DBU to activate DMC in the methylation of other nucleophiles, see: Shieh, W. -C.; Dell, S.; Repič, O. Org. Lett. 2001, 3, 4279.

(32) DMF was effective in promoting the DABCO-catalyzed N-methylation of indoles: Laurila, M. L.; Magnus, N. A.; Staszak, M. A. Org. Proc. Res. Dev. 2009, 13, 1199. 
(33) DMSO compares favorably with other dipolar aprotic solvent regarding health and safety concerns. See: ACS GCl Pharmaceutical Roundtable Solvent Selection Guide, Version 2.0, Issued March 21, 2011. [Online] http://surveys.acs.org/se.ashx?s=04BD76CC0E5496A7 (accessed Jan 4, 2013).

(34) Inorganic base-promoted reactions of DMC with nucleophiles at high temperature have been reported: Selva, M.; Benedet, V.; Fabris, M. Green Chem. 2012, 14, 189 and references cited therein. See also refs. 22 and 26.

(35) Feng, Y.; Wang, Y.; Landgraf, B.; Liu, S.; Chen, G. Org. Lett. 2010, 12, 3414.

(36) Sureshbabu, V. V.; Narendra, N. Protection Reactions. In Amino Acids, Peptides, and Proteins in Organic Chemistry; Hughes, A. B. Ed.; Wiley-VCH: Weinheim, 2011; Vol. 4, pp 34-36.

(37) Su, X.; Li, J.; Xiao, F.; Wei, W.; Sun, Y. Ind. Eng. Chem. Res. 2009, 43, 3685.

(38) Ouk, S.; Thiebaud, S.; Borredon, E.; Legars, P.; Lecomte, L. Tetrahedron Lett. 2002, 43, 2661.

(39) Candau, D. Synergistically UV-photoprotecting sunscreen compositions comprising camphorsulfonic acid/benzophenone compounds. U.S. Patent Application 20030161794, Aug 28, 2003.

(40) Intermediate 8 has been proposed in methylation with dimethyl dicarbonate: Goossen, L.; Dohring, A. Adv. Synth. Catal. 2003, 345, 943. Also see ref. 32. Carbonyl substitution at DMC has been observed with a variety of nucleophiles, although not specifically in the case of carboxylic acids. See refs 17 and 18.

(41) De Sarkar, S.; Grimme, S.; Studer, A. J. Am. Chem. Soc., 2010, 132, 1190.

(42) Zhang, J.; Zhang, Y.; Zhang, Y.; Herndon, J. W., Tetrahedron Lett. 2003, 59, 5609.

(43) Leduc, A. B.; Jamison, T. F. Org. Proc. Res. Dev. 2012, 16, 1082.

(44) Yamamoto, Y. Adv. Synth. Catal. 2010, 352, 478.

(45) Heller, S. T.; Sarpong, R. Org. Lett. 2010, 12, 4572.

(46) Budesinsky, M.; Kulhanek, J.; Boehm, S.; Cigler, P.; Exner, O. Mag. Res. Chem. 2004, 42, 844.

(47) Harker, W. R. R.; Carswell, E. L.; Carbery, D. R. Org. Lett. 2010, 12, 3712.

(48) Liu, X.; Hartwig, J. F J. Am. Chem. Soc. 2004, 126, 5182.

(49) Iwasawa, N.; Hayakawa, S.; Funahashi, M.; Isobe, K.; Narasaka, K. Bull. Chem. Soc. Jpn. 1993, 66, 819.

(50) Zheng, J.; Yin, B.; Huang, W.; Li, X.; Yao, H.; Liu, Z.; Zhang, J.; Jiang, S. Tetrahedron Lett. 2009, 50, 5094.

(51) Rauniyar, V.; Hall, D. G. J. Org. Chem. 2009, 74, 4236.

(52) Kobayashi, M.; Minato, H.; Ogi, Y. Bull. Chem. Soc. Jpn. 1970, 43, 905. 